\title{
PENGARUH LAYANAN PENGUASAAN KONTEN DENGAN TEKNIK BERMAIN PERAN (ROLE PLAYING) DALAM MENINGKATKAN KECERDASAN EMOSI PADA SISWA SMP NEGERI 22 KOTA BENGKULU
}

\author{
Nora Putri Pepriyanti, Wasidi, Vira Afriyati \\ Prodi Bimbingan dan Konseling Fakultas Keguruan dan Ilmu Pendidikan \\ Universitas Bengkulu \\ norhaa.putri@yahoo.com,wasidi@unib.ac.id,vira_afriyati@unib.ac.id
}

\begin{abstract}
ABSTRAK
Penelitian ini bertujuan untuk mengetahui ada tidaknya pengaruh layanan penguasaan konten dengan teknik bermain peran (role playing) dalam meningkatkan kecerdasaan emosi pada siswa kelas VIII A SMP Negeri 22 Kota Bengkulu. Penelitian ini menggunakan metode preeksperimen. Jenis penelitian pre-eksperimental yang digunakan yaitu one-group pre-test dan post-test design. Sampel penelitian terpilih menggunakan teknik purposive sampling sebanyak 23 siswa. Teknik pengumpulan data menggunakan instrument skala kecerdasan emosi yang sebelum digunakan di uji terlebih dahulu validitas dan reliabilitasnya. Teknik analisis data yang digunakan adalah paired sample $t$ test. Hasil penelitian menunjukkan bahwa nilai t (22) $=-27.161$, denganSignifikansi (2-tailed) 0.000. Itu berarti nilai Sign. (2tailed) $(\mathrm{p}<0.05)$. Hal ini menunjukkan bahwa terdapat perbedaan yang signifikan antara kecerdasaan emosi siswa kelas VIII A sebelum dan sesudah diberikan layanan penguasaan konten dengan teknik bermain peran (role playing). Kesimpulan dari penelitian ini adalah kecerdasaan emosi dapat ditingkatkan melalui layanan penguasaan konten dengan teknik bermain peran (role playing).
\end{abstract}

Kata kunci : layanan penguasaan konten dengan teknik bermain peran (role playing), kecerdasaan emosi

\section{INFLUENCE OF CONTENT SERVICES USING ROLE PLAYING TECHNIQUES IN IMPROVING EMOTIONAL INTELLIGENCE IN SMP STUDENTS NEGERI 22 BENGKULU CITY}

\begin{abstract}
This study aims to determine whether there is influence of content mastery services with role playing techniques in improving emotional intelligence in students of class VIII A SMP Negeri 22 Kota Bengkulu. This research uses pre-experiment method. Type of preexperimental research used is one-group pre-test and post-test design. The sample of research was chosen by purposive sampling technique as many as 23 students. Technique of collecting data using instrument of scale of emotional intelligence which before used in first test of its validity and reliability. The data analytical technique used is paired sample t test. The results showed that the value of $t$ value $(22)=-27.161$, with significance (2-tailed) 0.000 . That means the value of Sign. (2-tailed) $(\mathrm{p}<0.05)$. This shows that there is a significant difference between the emotional intelligence of class VIII A students before and after being given content mastery service with role playing technique. The conclusion of this research is emotional intelligence can be improved through content mastering service with role playing technique.
\end{abstract}

Keywords : content services using role playing techniques, emotional intelligence Jurnal Ilmiah Bimbingan dan Konseling, Volume 1 Nomor 22018 FKIP Universitas Bengkulu 


\section{Pendahuluan}

Masa remaja adalah masa yang penuh emosi, seperti mudah sedih, putus asa, dan senang (Sarwono, 2011: 99). Pada umumnya emosi remaja tidak seimbang, seperti mudah tersinggung dan cengeng. Perubahan hormon dan pengalaman lingkungan terlibat dalam perubahan emosi di masa remaja. Banyak remaja tidak dapat mengelola emosinya secara efektif. Sehingga, remaja rentan mengalami depresi, mudah marah, mudah tersinggung, kurang mampu meregulasi emosi, yang selanjutnya dapat memicu munculnya berbagai permasalah seperti kesulitan akademis, penyalahgunaan obat, kenakalan remaja atau gangguan makan (Santrock2007: 202).

Pada hakikatnya kajian kecerdasaan emosi berkaitan dengan bagaimana menggunakan kemampuan emosi untuk mengenal dan mengendalikan diri sendiri serta memahami orang lain. Hal demikian sejalan dengan pemikiran yang mengkaji kecerdasaan emosional hanya dari dua sisi, pertama peningkatkan kecerdasaan emosional melalui pengembangan kesadaran diri, mengatur emosi dan motivasi diri, kedua menggunakan kecerdasaan emosional untuk berhubungan dengan orang lain. Goleman (1996: 44) menyebutkan bahwa kecerdasan emosional jauh lebih berperan dalam kesuksesan hidup dari pada kecerdasan intelektual. Goleman juga memperlihatkan bahwa kecerdasan intelektual (IQ) hanya menyumbang 20\% bagi kesuksesan, sedangkan $80 \%$ adalah sumbangan faktor kekuatan-kekuatan lain, diantaranya adalah kecerdasan emosional atau Emotional Quotient (EQ) yakni kemampuan memotivasi diri sendiri, mengatasi frustasi, mengontrol desakan hati, mengatur suasana hati (mood), berempati serta kemampuan bekerja sama.

Berdasarkan dari hasil observasi dan wawancara terhadap guru BK di SMP Negeri 22 pada tanggal 8 April 2017 bahwa masih banyak siswa yang tidak bisa mengontrol emosinya sendiri atau selalu bersikap agresif seperti melakukan tindak kekerasan terhadap teman sendiri, berkelahi karena hal yang sepele, bertemperamen tinggi. Selain itu, para siswa yang memasuki fase remaja di sekolah banyak yang merasa cemas dan depresi, hal tersebut ditunjukkan dengan perilaku seringkali merasa takut, sering merasa gugup dan sedih, serta selalu merasa tidak dicintai oleh lingkungan sekitar siswa juga selalu berpikiran negative dan belum bisa mengenali emosi sendiri.

Salah satu layanan bimbingan dan konseling yang dapat diterapkan untuk mengatasi persoalan ini adalah layanan 
penguasaan konten. Menurut Prayitno (2004: 2) layanan penguasaan konten merupakan suatu layanan bantuan kepada individu baik sendiri maupun dalam kelompok untuk menguasai kemampuan atau kompetensi tertentu melalui kegiatan belajar. Di dalam layanan penguasaan konten harus ada kompetensi atau konten yang diajarkan atau dibelajarkan kepada siswa dengan harapan siswa mampu menguasai konten atau kompetensi tersebut secara baik.

Prosedur pelaksanaan layanan penguasaan konten hampir sama dengan layanan klasikal. Layanan klasikal umumnya hanya memberikan informasi (materi) dan pengadaan sesi tanya jawab. Namun berbeda dengan layanan penguasaan konten. Di dalam layanan penguasaan konten, terdapat kegiatan lanjutan setelah penyampaian informasi (materi) dan sesi tanya jawab. Kegiatan lanjutan ini dapat berupa diskusi kelompok, latihan terbatas, survei lapangan, studi kepustakaan, percobaan, atau latihan tindakan.

Dalam penelItian ini teknik layanan penguasaan konten yang dapat digunakan yaitu teknik bermain peran(Role Playing).Bermain peran merupakan salah satu teknik/bentuk pembelajaran, dimana peserta didik ikut terlibat aktif memainkan peran-peran tertentu. Melalui kegiatan bermain yang menyenangkan, individu berusaha untuk menyelidiki dan mendapatkan pengalaman, baik pengalaman dengan dirinya sendiri, orang lain maupun dengan lingkungan yang ia tempati. Djago Taringan (1990:445) mengemukakan bahwa Role Playing atau bermain peran adalah suatu cara penguasaan bahan pelajaran melalui pengembangan imajinasi dan penghayatan siswa terhadap suatu tokoh tertentu.

\section{Metode Penelitian}

Penelitian eksperimen dibagi menjadi empat jenis penelitian, ke empat jenis penelitian itu adalah "pre-eksperimental design, true eksperimental design, factorial design dan quasi eksperimental design" (Sugiyono 2008: 108). Penelitian ini menggunakan metode pre-eksperimen. Jenis penelitian pre-eksperimental yang digunakan yaitu one-group pre-test dan post-test design. One-group pre-test dan post-test design digunakan untuk membandingkan dengan keadaan sebelum diberi perlakuan dan sesudah diberi perlakuan. Pengukuran pertama (pre test) dilakukan untuk melihat kondisi sampel sebelum diberikan perlakuan yaitu tingkat kecerdasaan emosi siswa sebelum diberikan 
layanan penguasaan konten teknik bermain peran (role playing), dan pengukuran kedua (post test) dilakukan untuk mengetahui tingkat kecerdasaan emosi siswa setelah diberikan layanan penguasaan konten teknik bermain peran (role playing).

Desain penelitian ini digambarkan sebagai berikut :

\section{Pengukuran Pengukuran}

(Pre-test) Perlakuan (Post-test)

\begin{tabular}{|lll|}
\hline $\mathrm{O}_{1}$ & $\mathrm{x}$ & $\mathrm{O}_{2}$ \\
\hline
\end{tabular}

Bagan Desain Penelitian

Keterangan :

$\mathrm{O} 1=$ Pengukuran pertama $($ pre test $)$, kecerdasaan emosi siswa sebelum diberikan perlakuan yang diukur dengan menggunakan instrumen berupa kuesioer $\mathrm{X}=$ Perlakuan atau (Treatment), pelaksanaan layanan penguasaan konten dengan tekni bermain peran (role playing) siswa pada kelas VII A di SMP Negeri 22 Kota Bengkulu

$\mathrm{O} 2=$ Pengukuran kedua $($ post test), kecerdasaan emosi siswa sesudah diberikan layanan penguasaan konten teknik bermain peran (role playing) dengan meggunakan istrumen yang sama pada pengukuran pertama.

Waktu penelitian dilaksanakan pada semester genap tahun ajaran 2016/2017. Adapun tempat penelitian adalah SMP
Negeri 22 Kota Bengkulu Kecamatan Muara Bangkahulu.

Subjek dalam penelitian ini adalah seluruh siswa kelas VIII SMP Negeri 22 Kota Bengkulu yang terdiri dari 3 kelas, yaitu kelas VIII A, kelas VIII B dan kelas VIII C sedangkan yang menjadi sampel dalam penelitian ini adalah satu kelas VIII A.

Menurut Sugiyono (2008: 117) populasi adalah wilayah generalisasi yang terdiri atas obyek atau subyek yang mempunyai kualitas dan karakteristik tertentu yang ditetapkan oleh peneliti untuk dipelajari dan kemudian ditarik kesimpulannya. Dalam penelitian ini yang berkedudukan sebagai populasi pada penelitian ini yaitu siswa kelas VIII SMP Negeri 22 Kota Bengkulu yang berjumlah 60 Siswa.

Menurut Zuriah (2009: 119) sampel sering didefinisikan sebagian dari populasi, sebagai contoh (master) yang diambil dengan menggunakan cara-cara tertentu. Pengambilan sampel pada peneliti ini adalah teknik purposive sampling yaitu teknik pengambilan sampel dengan pertimbangan tertentu. Menurut Hadi (2001: 226), purposive sampling adalah pemilihan sekelompok subjek didasarkan atas ciri-ciri atau sifat tertentu yang dipandang mempunyai sangkut paut yang 
erat dengan ciri-ciri atau sifat-sifat populasi yang sudah diketahui sebelumnya. Dalam penelitian ini, peneliti mengambil sampel kelas VIII A yang berjumlah 23 siswa, sesuai dengan pertimbangan-pertimbangan berikut yaitu (1) banyak nya siswa yang belum bisa mengontrol emosi, (2) siswa yang bertengkar satu sama lain, (3) kurang bersemangat, (4) kasar terhadap yang lain, (5) masih banyak siswa yang egois dan (6) mementingkan kepentingan sendiri daripada kepentingan orang lain.

Data yang diperoleh dari suatu penelitian tentunya harus melalui pengolahan data. Analisis data yang akan dilakukan menggunakan software Statistical Packages for Social Science 16.0 for Windows. Analisis deskriptif dianalisis dengan statistika sederhana (rerata, simpangan baku, kategori).

\section{Uji Validitas}

Menurut Sekaran (dalam Sarjono \& Julianita, 2011:35) menyatakan validitas adalah bukti instrument, teknik atau proses yang digunakan untuk mengukur sebuah konsep benar-benar mengukur konsep yang dimaksudkan. Uji validitas bertujuan untuk mengukur valid tidaknya suatu item pernyataan. Relevansi indikator keperilakuan dan dengan tujuan ukur sebenarnya sudah dapat dievaluasi lewat nalar dan akal sehat yang mampu menilai isi skala mendukung konstrak teoritik yang diukur

Pada penelitian ini, validasi isi dilakukan dengan mengkonsultasikan angket kepada tiga ahli Dosen Bimbingan dan Konseling Universitas Bengkulu. Selanjutnya diuji cobakan kepada 40 orang siswa. Kemudian penarikan sampel di ambil dari pengisian angket. Apabila angket sudah dinyatakan valid, angket tersebut akan digunakan sebagai alat ukur untuk kecerdasaan emosi siswa kelas VIII A di SMPN 22 Kota Bengkulu.

Berdasarkan perhitungan uji validitas menggunakan SPSS (statistical packages for social science) for window release 16,00 pada variabel terikat diketahui bahwa dari 44 butir item instrumen angket kecerdasaan emosi ada 34 item yang valid yaitu terdiri dari nomor : 1, 2, 3, 5, 6, 7, 8, $9,10,11,13,15,16,17,18,19,21,22,23$, $24,26,27,32,33,34,36,37,38,39,41$, 42, dan 43 . Secara keseluruhan 44 butir item angket kecerdasaan emosi dalam uji validitas tersebut nilai pada corrected itemtotal correlationnya menunjukkan lebih besar dari $(0,312)$ sehingga item teresbut secara keseluruhan menujukkan valid. Pada item butir angket yang tidak valid ada 10 butir item, yaitu 4, 12, 19, 20, 25, 28, 30, 31, 35, dan 40. Secara keseluruhan 10 butir instrumen angket perilaku prososial dalam 
uji validitas tersebut nilai pada corrected item-total correlationnya menunjukkan lebih kecil dari (0,312) sehingga item tersebut secara keseluruhan menunjukkan tidak valid.

\section{Reliabilitas}

Reliabilitas dilakukan untuk menunjukkan bahwa suatu instrumen cukupdapat dipercaya untuk digunakan sebagai alat pengumpul datareliabilitas merupakan salah satu ciri atau karakter utama instrumen pengukuran yang baik. Instrumen yang reliabel atau sudah dapat dipercaya, akan menghasilkan data yang dapat dipercaya juga. Pengujian reliabilitas pada pemahaman karier dalam penelitian ini menggunakan scale pada Statistical Packages for Social Science (SPSS) for Window Release 16,00. Jika $\mathrm{r}$ hitung > r tabel yaitu 0,800 maka instrumen dapat dikatakan reliabel.

\section{Tabel 1.}

\section{Uji Reliabilitas Reliability Statistics}

Cronbach's AlphaN of Items

0,85834

Berdasarkan tabel 1 menunjukkan Cronbach's Alpha sebesar 0,858 dengan jumlah 34 item berarti Cronbach's Alpha> 0,80 maka instrumen tes pemahaman dinyatakan memiliki reliabilitas yang baik.

\section{Hasil dan Pembahasan}

Dalam menentukan kategori perolehan skor subjek penelitian, diawali dengan mencari mean dan standar deviasi, dengan menggunakan software statistical packages for social scince (SPSS) versi 16,00 menunjukkan bahwa variabel kecerdasan emosi, dengan subjek penelitian 23 orang dan jumlah item angket 34 . Perolehan nilai minimum pada skor hipotetik diperoleh dari jumlah item dikalikan dengan nilai terkecil pada pilihan item skala Likert dan diperoleh skor minimum 34. Nilai maksimum pada skor hipotetik yaitu dengan dikalikan jumlah item dengan nilai terbesar yaitu 5 pada skala Likert hasilnya yaitu 136. Untuk menentukan mean hipotetik yaitu jumlah skor minimum dikalikan dengan 3 hasilnya yaitu 85, sedangkan untuk mencari standar deviasi hipotetik adalah dengan cara skor maksimum dikurang skor minimum dibagi 6 hasilnya yaitu 17.

Dari hasil angket pretest, diperoleh hasil yang menunjukkan bahwasiswa yang tergolong kategori sangat rendah $(\leq 60)$ berjumlah 3 orang, dalam kategori rendah (77 - 61) berjumlah 9 orang, kategori sedang (85 - 76) berjumlah 6 orang, kategori tinggi (94 - 84) berjumlah 3 orang dan kategori sangat tinggi (>111-93) berjumlah 1 orang. 


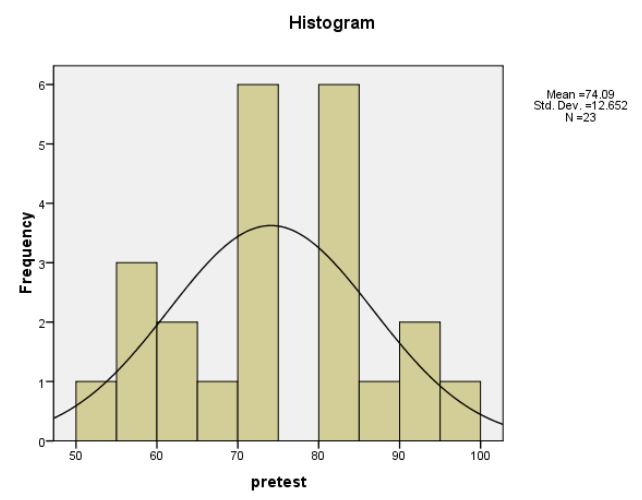

Gambar 1. Histogram Kategori Pretest

Dari Gambar 1 pada hasil pretest, dengan jumlah subjek 23 orang siswa, dapat dilihat bahwa kurva di atas menunjukkan bahwa kurva berbentuk lonceng. Berdasarkan histogaram di atas bisa dideskripsikan bahwa Mean $=74,09$ median=73,00, Mode $=56$ dan standar deviasinya adalah 12,625. Maka dapat disimpulkan bahwa distribusi data juling negatif yang berarti kecedasan emosi banyak yang kurang.

Setelah diberikan layanan penguasaan konteng teknik bermain peran (role playing), peneliti memberikan angket posttest kepada siswa. Dari hasil angket posttest diperoleh hasil yang menunjukkan peningkatan tingkat. Dapat dilihat dari Histogram 2 yaitu sebagai berikut :

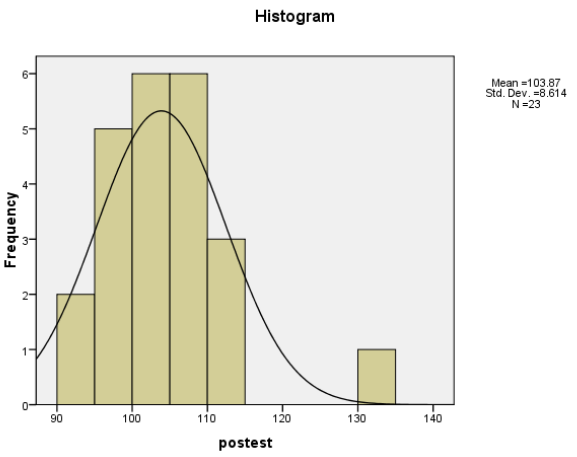

Gambar 2. Histogram Kategori Posttest Berdasarkan Gambar 2 tersebut, dengan jumlah subjek 23 orang siswa, dapat dilihat bahwa kurva di atas menunjukkan bahwa kurva berbentuk lonceng. Berdasarkan histogaram di atas bisa dideskripsikan bahwa Mean $=103.87$ Median $=102.00$, Mode $=102$ dan standar deviasinya adalah 8.614. Maka dapat disimpulkan bahwa distribusi data juling positif yang berarti kecedasan emosi meningkat.

Hasil olah analisis statistik kecerdasanemosi siswa sebelum dan setelah diberikan layanan penguasaan konten dengan teknik bermainperan (role playing), dari jumlah 23 siswa dapat diketahui bahwa mean sebelum perlakuan yaitu sebesar 74.09 dan mean setelah perlakuan yaitu sebesar 103.87, standar deviasi sebelum perlakuan yaitu sebesar 12.652 dan standar deviasi setelah perlakuan yaitu sebesar 8.614, skor minimum sebelum perlakuan yaitu sebesar 57 dan skor minumum setelah 
perlakuan yaitu sebesar 90, skor maksimum sebelum perlakuan yaitu sebesar 97 dan skor minimum setelah perlakuan yaitu sebesar 130.Maka dapat disimpulkan bahwa layanan penguasaan konten teknik bermain peran (role playing) dapat meningkatkan kecerdasaan emosi siswa di SMP Negeri 22 Kota Bengkulu.

Hasil uji hipotesis menunjukkan bahwa nilai $\mathrm{t}(22)=-27.161$, dengan Signifikansi (2-tailed) 0.000. Itu berarti nilai Sign. (2-tailed) $(\mathrm{p}<0.05)$. Berdasarkan kriteria penerimaan atau penolakan hipotesis itu berarti $\mathrm{H}_{0}$ ditolak, dengan demikian dapat disimpulkan bahwa terdapat perbedaan yang signifikan kecerdasan emosi sebelum (dengan mean $=74.09$ ) dan setelah layanan penguasaan konten $($ mean $=$ 103.87). Mean setelah dilaksanakan layanan penguasaan konten lebih tinggi dibanding mean sebelum layanan penguasaan konten. Artinyaadapengaruhlayananpenguasaankont endenganteknikbermainperan (role playing) terhadap kecerdasan emosi.

Kecerdasan emosi (EQ) merupakan karakteristik seseorang sebagai suatu jenis kecerdasan yang amat perlu ditingkatkan dan Kecerdasaan emosi merupakan penggerak yang dapat menimbulkan aspekaspek energi, kekuatan, daya tahan, dan stamina. Kecerdasan emosi adalah kemampuan merasakan dan memahami secara lebih efektif terhadap daya kepekaan emosi yang mencakup kemampuan memotivasi diri sendiri atau orang lain, pengendalian diri, mampu memahami perasaan orang lain dengan efektif, dan mampu mengelola emosi yang dapat digunakan untuk membimbing pikiran untuk mengambil keputusan yang terbaik.

Sama seperti yang dikatakan Grewal dan Salovey (2005: 331) emotional intelligence is a more focused concept menyatakan bahwa Kecerdasan emosi memiliki peran yang penting dalam kehidupan. Kecerdasan emosi mempengaruhi semua aspek kehidupan, apalagi dalam kehidupan, manusia tidak terlepas dari hubungan dengan orang lain, jadi kita harus bias memposisikan diri dengan baik, memperbaiki perasaan yang negative sebelum perasaan itu berubah menjadi kebencian atau sesuatu hal yang merugikan diri sendiri. Penelitian ini bertujuan untuk mengetahui perbedaan mengenai kecerdasan emosi siswa sebelum dan setelah diberikan layanan penguasaan konten dengan teknik bermain peran (role playing). Penelitian ini menggunakan rancangan one group pretest andposttest design. Berdasarkan rancangan tersebut sasaran yang dijadikan penelitian adalah siswa kelas VIII A. Penelitian ini dilakukan selama bulan Mei dengan 7 kali pertemuan 
termasuk pretest dan postest. Pretest dan posttest yang diberikan kepada siswa berupa angket dan treatment yang diberikan kepada siswa terdiri dari 5 aspek kecerdasan emosi yaitu mengenali emosi, mengelola emosi, motivasi diri sendiri, empati dan membina hubungan dengan orang lain.

Secara keseluruhan berdasarkan data pretest dan posttest yang telah diuji menggunakan Software Statistical Packages for Social Science (SPSS) for Window Release 16.0, maka hasil pengujian hipotesis penelitian diperoleh hasil yaitu ada pengaruh layanan penguasaan konten dengan teknik bermain peran (role playing) terhadap kecerdasan emosi siswa, dapat dilihat nilai $\mathrm{t}(22)=-27.161$, dengan Signifikansi (2-tailed) 0.000. Itu berarti nilai Sign. (2-tailed) $(\mathrm{p}<0.05)$. Berdasarkan kriteria penerimaan atau penolakan hipotesis itu berarti $\mathrm{H}_{0}$ ditolak, dengan demikian dapat disimpulkan bahwa terdapat perbedaan yang signifikan kecerdasan emosio sebelum (dengan mean $=74.09$ ) dan setelah layanan penguasaan konten $($ mean $=$ 103.87). Mean setelah dilaksanakan layanan penguasaan konten lebih tinggi dibanding mean sebelum layanan penguasaan konten. Artinya ada pengaruh layanan penguasaan konten dengan teknik bermain peran (role playing) terhadap kecerdasan emosi.
Pemberian layanan penguasaan konten dalam penelitian ini sesuai dengan pendapat Menurut Prayitno (2004: 2) yaitu layanan penguasaan konten (PKO) merupakan layanan bantuan kepada individu (sendirisendiri ataupun dalam kelompok) untuk menguasai kemampuan atau kompetensi tertentu melalui kegiatan belajar. Menurut Prayitno (2004: 2) tujuan layanan penguasaan konten dapat dilihat pertama dari kepentingan individu atau klien mempelajarinya, dan kedua isi konten itu sendiri.

Teknik dalam layanan ini adalah teknik bermain peran (role playing). Menurut Zaini, H. Munthe, B, \&Aryani, S. A. (2008: 98) metode pembelajaran (role playing) merupakan suatu aktivitas pembelajaran terencana yang dirancang untuk mencapai tujuan-tujuan pendidikan yang spesifik dan merupakan salah satu bentuk permainan pendidikan yang dipakai untuk menjelaskan peranan, sikap, tingkah laku, nilai dengan tujuan menghayati perasaan, sudut pandang dan cara berpikir orang lain.

Dapat disimpulkan bahwa ada perbedaan kecerdasaan emosi siswa sebelum dan sesudah diberikan layanan penguasaan konten dengan teknik bermain peran (role playing )pada siswa kelas VIII A di SMP Negeri 22 Kota Bengkulu. Hal 
ini menunjukkan bahwa layanan penguasaan konten dengan teknik bermain peran (role playing) meningkatkan kecerdasan emosi siswa

\section{Kesimpulan}

Berdasarkan hasil penelitian yang telah dilakukan dapat ditarik kesimpulan sebagai berikut:

Berdasarkan hasil olah pre-test dapat disimpulkan bahwa rata-rata kecerdasaan emosi siswa sebelum diberikan treatment berupa layanan bimbingan dengan rata-rata skor yang rendah.

Kecerdasaan emosi setelah diberikan treatment berupa layanan penguasaan konten dengan teknik bermain peran (role playing) mengalami peningkatan skor yang rendah menjadi skor yang lebih tinggi dan meningkat.

Ada pengaruh dari treatment (perlakuan) menggunakan layanan pengasaan konten dengan teknik bermain peran (role playing). Hal ini dapat dibuktikan dari hasil analisis data yang menyebutkan bahwa Ho ditolak yang berarti terdapat penggaruh layanan penguasaan konten dengan teknik bermain peran (role playing) terhadap kecerdasaan emosi.

\section{Daftar Pustaka}

Goleman, Daniel. (1996). emotional Intelligence Kecerdasaan Emosional Mengapa EL Lebih Penting Daripada IQ. Jakarta: PT Gramedia Pustaka Utama.

Grewal,D, Salovey,P. (2005). "Feeling Smart: The Science of Emotional Intelligence", American Scientist, Vol.93, No.4, 330-339.

Prayitno. (2004) . L1-L9. Prodi BK FIP UNP. Padang

Santrock, J.W. (2007). Ahli Bahasa: Shinto, B.A. \& Sherly, S. Remaja. Jakarta: Penerbit Erlangga.

Sarwono, S.W. (2011). Psikologi Remaja. Jakarta: Rajawali Pers.

Sugiono. (2008). Metode penelitian pendidikan: pendekatan kuntitatif, kualitatif, dan R \&D. Bandung: Alfabeta.

Zaini, H., Munthe, B., \& Aryani, S. A. (2008). Strategi Pembelajaran Aktif. Yogyakarta: Pustaka Insan Madan

Zuriah, Nurul. (2009). Metodologi Penelitian Sosial dan Pendidikan Teori Aplikasi. Jakarta: Bumi Aksara 